\title{
New Disease Reports \\ First report of Bean yellow mosaic virus on Cape gooseberry in India
}

Charanjeet Kaur, Rashmi Raj, Susheel Kumar and SK Raj*

Plant Molecular Virology Laboratory, CSIR-National Botanical Research Institute, Rana Pratap Marg, Lucknow-226001, UP, India

*E-mail: skraj2@rediffmail.com

Received: 28 Mar 2014. Published: 05 May 2014. Keywords: Physalis peruviana, mosaic disease

Cape gooseberry (Physalis peruviana, Solanaceae) is an important crop cultivated in tropical, subtropical and temperate areas for nutritional and medicinal purposes. During a survey in April 2013, a severe mosaic disease was observed on most of the $P$. peruviana plants growing in a farmer's field at Barabanki, India. Naturally infected plants exhibited mosaic, leaf distortion and stunting symptoms (Fig. 1a). Sap from infected leaves of $P$. peruviana was inoculated on seedlings of $P$. peruviana, Chenopodium amaranticolor, Datura inoxia, Petunia hybrida and Nicotiana glutinosa. Sap inoculations resulted in local lesions on $C$. amaranticolor 10 days post inoculation (dpi), and systemic mosaic and leaf crinkling on $P$. peruviana, D.inoxia and P. hybrida (Fig. 1b-d), but not on N. glutinosa 30 dpi. The symptoms on inoculated $P$. peruviana were similar to those of naturally infected $P$. peruviana. Flexuous filamentous virus particles of $\sim 750 \times 12$ $\mathrm{nm}$ were observed in leaf dip preparations using an electron microscope, indicating the presence of a potyvirus.

Total RNA was extracted from leaf samples of three symptom-bearing and one healthy $P$. peruviana plant and tested by RT-PCR using degenerate potyvirus primers (Ha et al., 2008). A 700 bp band was amplified from all three plants with symptoms but not from the healthy sample, suggesting potyvirus infection. All amplicons were cloned and sequenced (GenBank Accession Nos. KJ191461- KJ191463). The sequences were 98-99\% identical to each other and had the highest identity (99\%) and a close phylogenetic relationship with an isolate of Bean yellow mosaic virus (BYMV; JX177278) isolated from Diuris sp. in Australia (Fig. 2). Therefore, the virus associated with mosaic disease of $P$. peruviana was identified as BYMV. According to the literature, Cucumber mosaic virus in
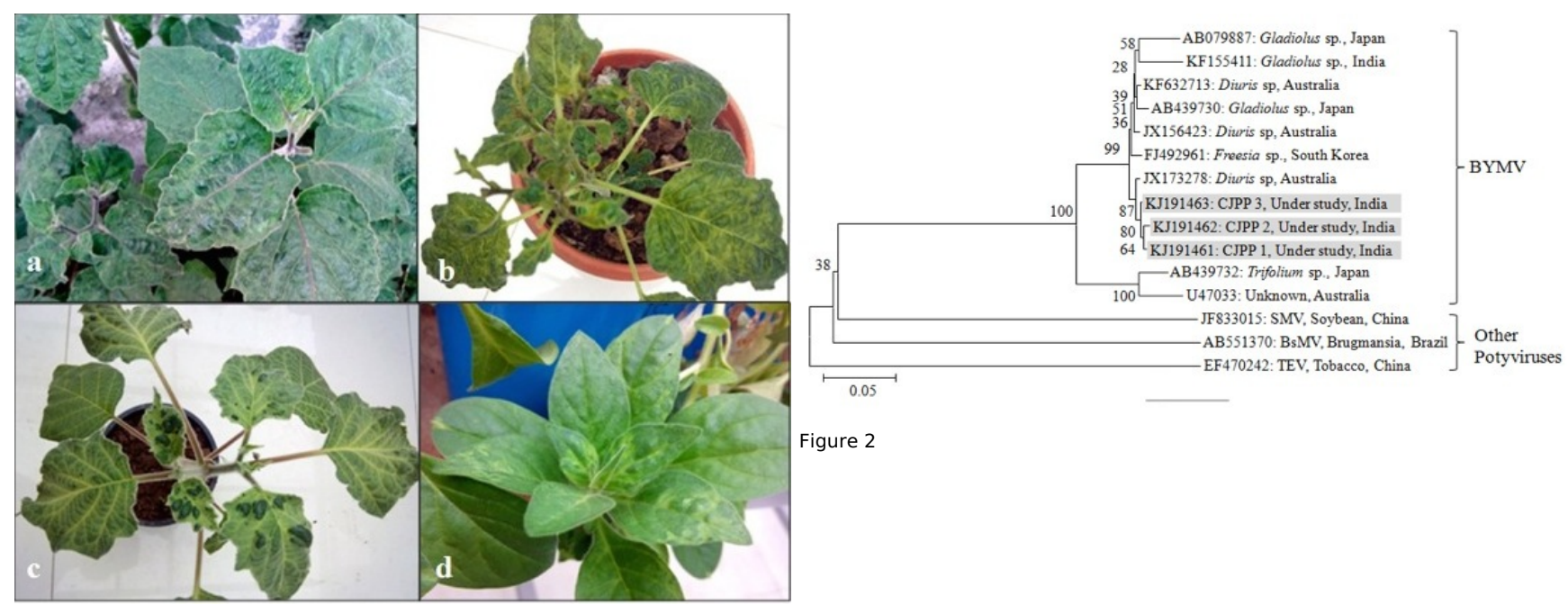

India (Gupta \& Singh, 1996), Colombian datura virus in Hungary (Salamon \& Palkovics, 2005), Tomato spotted wilt virus in Transkei (da Graça, et al., 1985) and a tospovirus in Brazil (Eiras et al., 2012) have been found to infect $P$. peruviana. However, the natural occurrence of BYMV has not been previously reported. To our knowledge, this is the first report of natural occurrence of BYMV on P. peruviana.

\section{References}

da Graça JV, Trench TN, Martin MM, 1985. Tomato spotted wilt virus in commercial Cape gooseberry (Physalis peruviana) in Transkei. Plant Pathology 34, 451-453.

http://dx.doi.org/10.1111/j.1365-3059.1985.tb01390.x

Eiras M, Costa IFD, Chaves ALR, Colariccio A, Harakava R, Tanaka FA, Garcêz, RM, Silva LA, 2012. First report of a tospovirus in a commercial crop of Cape gooseberry in Brazil. New Disease Reports 25, 25. http://dx.doi.org/10.5197/j.2044-0588.2012.025.025

Gupta SP, Singh BR, 1996. Severe mosaic of cape gooseberry due to Cucumber mosaic virus. Indian Journal of Virology 12, 155-156.

Ha C, Coombs S, Revill PA, Harding RM, Vu M, Dale JL, 2008. Design and application of two novel degenerate primer pairs for the detection and complete genomic characterization of potyviruses. Archives of Virology 153, 25-36. http://dx.doi.org/10.1007/s00705-007-1053-7

Salamon P, Palkovics L, 2005. Occurrence of Colombian datura virus in Brugmansia hybrids, Physalis peruviana L. and Solanum muricatum Ait. in Hungary. Acta Virologica 49, 117-122.

Figure 1 